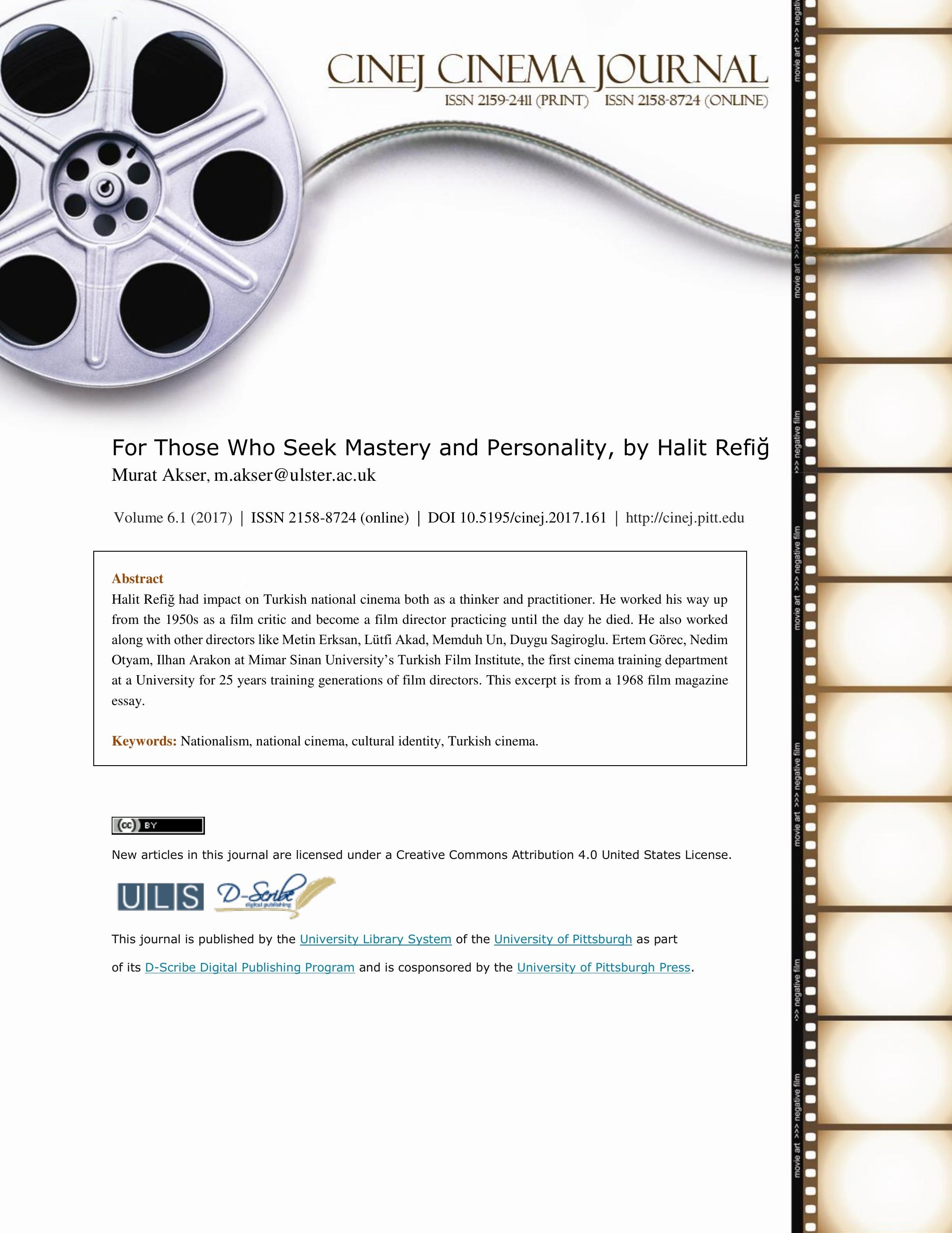




\section{For Those Who Seek Mastery and Personality, by Halit Refiğ Murat Akser}

\section{Introduction}

$45^{\text {th }}$ Antalya Golden Orange Film Festival was suspended for a day when the news of the film director Halit Refíğ's (1934-2009) death exploded on the scene. All attending actors, director, producers and technicians got on planes to attend his funeral. Refiğ had received the very first best film price back in 1964 when the festival was first launched and had won on many occasions alter. His memory is reviving once again in 2014 when the festival organizers invited his widow, Ms. Gulper Refiğ, to donate this first award, the statute of a goes holding a golden apple, to recreate this award fifty year later. Halit Refiğ had impact on Turkish national cinema both as a thinker and practitioner. He worked his way up from the 1950s as a film critic and became a film director practicing until the day he died. He also worked along with other directors like Metin Erksan, Lutfi Akad, Memduh Un, Duygu Sagiroglu. Ertem Gorec, Nedim Otyam, Ilhan Arakon at Mimar Sinan University's Turkish Film Institute, the first cinema training department at a University for 25 years training generations of film directors. This except from a 1968 film magazine essay. Translated pieces of Refiğg's film writings from different film magazines are coming out from Film Studies by Manchester University Press (Akser and Durak-Akser 2017). There are articles and books illustrating Refiğ's debate with Sinematek group in the 1960s and 1970s. More research into his films and writings is needed as Refiğ is still relevant after sixty-three years since he first got published. This translation is an important first step towards that direction. 


\section{For Those Who Seek Mastery and Personality}

Hal erenler halidir, yol erenler yoludur, Gafil olman sofiler, değen üstad koludur. [The condition is the condition of saints, the way is the way of saints, Don't be careless, Sufis, what touched upon you is the hand of the master.]

Bektaşi nasip ayini [Bektasi rite of luck]

To say "No film has been ever made in Turkey so far" is not a sufficient basis for making a good film. Denialism is not the way of good art, but a way for incapable bluffing. If those who love to think on cinema in Turkey want to rediscover certain things, and do not want to repeat what has been already told, they have to know what has been done and what has been achieved so far. One of the people who took the art of cinema in Turkey to the furthest is Lütfi Akad, and the other one is Metin Erksan. National Turkish cinema can only be developed through researching on and evaluating their and other certain filmmakers' works. Otherwise, with the poems of admiration of "I love the works of American and European filmmakers!", no work can be achieved. We, in this chapter, would like to mention a few words on Akad and Erksan's works and our cinema's some best films.

In one of his talks (Görüntü, [Image], February 1968), Lütfi Akad says that he considers "Hudutların Kanunu" [Law of Borders] as his first film. That a director, who makes approximately thirty films from "Vurun Kahpeye" [Hit the Whore] in 1949 to "Hudutların Kanunu" in 1966 in seventeen years, discards the work of so many years is outstanding. Especially when this director is the founder of Turkish cinema language and an artist who broke fresh ground in his jon, like Lütfi Akad. 
Lütfi Akad explains this in another talk in May magazine as such: "We used to make Western wannabe films, we watched and liked our films ourselves... In the mistake of westernism, cinema authors were our partners in crime." After he mentions the help of Kemal Tahir's studies and Sencer Divitçioğlu's scientific studies in the rising of self-awareness of certain Turkish filmmakers, he says "We want to go back to our national cultural resources and make films based on our own people's texture". In those circumstances, it can perhaps be seen natural for him to put Akad's film works starting with an entertainment including accordion playing and tango in Büyükada forests in "Kanun Namına" [In The Name Of Law] and reaching foggy and misty shores of "Yalnızlar Rıhtımı" [Port of Loners], constantly influencing Turkish cinema for ten years and dominating this art away by labelling it as "the effort of westernism". Yet, the fact that other than Islamists, all the Turkish intellectuals was conditioned to the West is a situation which considerably eases Akad's fault and makes his works unnecessary to be put away. Otherwise, we would have to deny all the ideological and artistic movements supported by governmental powers in the skeleton of the society or the government itself since Tanzimat [Political reforms], the poetry from Namık Kemal to Nazım Hikmet, the novel from Halit Ziya to Yaşar Kemal, the painting from Şeker Ahmet Paşa to Nuri İyem and we would have to burn down all prominent architectural pieces from Dolmabahçe Palace the Ankara Opera Building, and Turkey has no tolerance to handle such luxury. These works have value as being the exemplary proofs of Turkish artist's efforts which ruptured from the people by being related to mostly inefficient goals and which was no good for anyone, and their efforts to find a way in a marsh in a bewildered and dark moment of Turkish history. Even though we look at them from another perspective today, Akad's films before "Hudutların Kanunu” undoubtedly keep their importance in a certain period of Turkish cinema. Moreover, the experience he gained in those films and such a documentary film as “Tanrı'nın 
Bağış1 Orman" [Forest, God's Blessing] have a great share in making "Hudutlar Kanunu” Akad's best film.

Even though "Hudutların Kanunu" is based on a bad script, it reaches its goal through its superior narrative power which goes beyond this deficiency and it is a cinematic narrative triumph both for Akad and Turkish cinema. The script which tries to enlighten social facts of the people in Southeastern Anatolia, neighbor to Syria tries to see the issues without emphasizing on the regional characteristics and from the perspective of some desk-bound theories. Therefore, the smuggling events which are frequently encountered in Urfa and surroundings where the film was shot are based on the soil infertility and the frauds of landlords. In fact, it is known that $43 \%$ of Urfa region soil is arable and it has been feeding people since the first emergence of civilization in Anatolia and Mesopotamia. The most important historical feature of the region is that the economic relations of the region have expanded towards south, Syria and Mesopotamia, instead of northwest, Anatolia. Historical documents show that in the era of Hittite who founded the first political unity in Anatolia, Urfa was under the influence of Assyrian and Babel economy even when it was included in this union. Seljuk Turks took Urfa from Arabs, but after a while, they lost it to the Crusade Empire in Jerusalem as an earldom. In Ottoman Period, Urfa was a district bound to Halep province. That it is surrounded by mountains obliged this region to expand only towards south in terms of economy. Smuggling, in other words trade with Syria is the result of this historical feature. To change this situation is neither possible through laying mines in the borderlines, nor sending teachers as goodwill ambassadors or suppressing the landlords. As long as the economy of the region is not developed towards Anatolia through industrialization, this sickness will continue to exist. 
And Akad himself admits that the relations between army officer-bandit-teacher are unreal by saying "The relationship between government and individuals in this territory are not as seen in this film". All these lead "Hudutların Kanunu", which Akad gives as an example of "folk cinema", to be a good willingly but mistaken troop film in terms of ideology even though it is a "folk" cinema in terms of economic basis just like the $95 \%$ of Turkish films.

Apart from all, Akad creates an efficient world in a reality which reaches beyond the boundaries of the script with a mastery in using the material and vivacious images which he puts in a sequence. The real value of "Hudutların Kanunu" lies behind these characteristics of form and narrative which should be focused on as a cinema work.

Most of the film was shot in the place where the events happened. Few films could be said to use natural places In such mastery. The places in "Hudutların Kanunu" are not one of those which are seen behind the events and mostly used to be beautiful or effective; on the contrary there are one of the vivacious dramatic basics which live with them. Not only does it refer to Akad's success in observation but it also put forwards his power as an image maker with his mastery in harmony between the scenes in Istanbul and Urfa. As long as Hayri Esen's healthy and fluid voice which speaks with a clean Istanbul accent, except Pervin par who seems to be there mistakenly from the films country girl who wears high heels and whose hair is stylish, all the actors, notably Y1lmaz Güney, local characters with their clothes, actions, sheep and horses creates an outstanding, pure, realist and dynamic picture far away from adornment, unnecessary camera actions and mis-en-scene inappositeness in the Akad's direction and a setup without breaks. One of the summits which Turkish cinema have reached is "Hudutların Kanunu". It is a respond to those who writes ridiculous things such as "babbling instead of image language" without watching Turkish films. 
Akad's approach on this is also valuable besides its visual success. Social events are important in western cinema in terms of its influence on individuals. What is caused by it is usually extreme violence demonstrations as a sign of individualism.

Akad does not approach his issue from this sick individualist perspective. He sets his film properly like a Turkish artist, with cold feet unique to the Eastern wise, without being too familiar with his individuals, without over-evaluating their issues and their shares in the events, without being curious about what they do in the bathroom or bedroom, yet in a certain social system in terms of relations of the people.

The fact that the difference between individualist Western art of which roots are based on Renaissance humanism and Eastern arts of which roots are either based on a collective conscience no matter whether it is Holy justice or social justice is obvious in "Hudutların Kanunu" shows that Akad has taken solid steps in the founding of national Turkish cinema in terms of form and narrative.

Besides these can be seen also in Akad's "Kizılırmak-Karakoyun", one must say that this film is way behind "Hudutların Kanunu". Historical commentary which "Kızılırmak-Karaboyun" - of which script was formed out of the union of two folk stories - brings is only valid for classed western societies of which roots are based on feudality. It reflects the characteristics of Ottoman society of the time wrongly. Capital saving through usury and class issues are valid for Western societies where there is private property in the land. Commentary of "Kizllırmak-Karakoyun" is nothing but a desk-bound analysis for Ottoman society which is bound to state property for land and brings a problematic approach to the nomadic Turkmen issue which is a very serious situation for Ottoman Empire. And in terms of cinema's benefiting from folklore, in the film there is no 
more progressive and improved example than what Atıf Y1lmaz made in "Alageyik" and "Karacaoğlan". That Turkmens wander in the mountains in such dresses as sewed by a tailor as if in a folk opera scene can only be tolerated when the film is accepted to be narrating a fairy tale.

Despite all, "Kızılırmak-Karakoyun" becomes one of the valuable pieces on Turkish cinema because it provides maximum benefit from limited material thanks to its pure and proper narrative -which is one of Akad's personal marks-, its dramatic structure developing like a chess match and modest but masterly scene arrangements. After Lütfi Akad tried to teach how to make films like a western director for fifteen years, now he is teaching how to make films like Turk. Our thinkers and writers on cinema should focus on Lütfi Akad's geometrical cinema language and analyze it deeply rather than thinking over Resnais' or Welles' mastery. Undoubtedly, Turkish cinema will learn more from Lütfi Akad than western masters.

Metin Erksan is the most popular Turkish film director; however, this interest is usually directed at his activities rather than its films. Even "Susuz Yaz" [Dry Summer] which was awarded "Golden Bear" in Berlin Festival could not be analyzed thoroughly by out writers. (Giovanni Scognamillo whose analysis on Metin Erksan can be found in the magazine Sinema 65 is excluded). The most interesting essay on "Susuz Yaz" was not unfortunately written by a cinema writer, but by Aziz Nesin. "Sevmek Zamanı” and "Ölmeyen Aşk” [Undying Love], among Erksan's later films, encountered even more fearful silence. This situation shows that even Metin Erksan could not escape from the ungrateful fate which stands against Turkish filmmakers.

What "Susuz Yaz" narrates and what kind of a film it is was hardly ever focused on, yet lobby activities in Berlin Festival were investigated in detail, including bedroom gossips of jury members. In fact, "Susuz Yaz" is not a coincidence but a result of Metin Erksan's cinema works starting from “Karanlık Dünya”. Erksan attempted to shoot a film narrating Aşık Veysel’s life in 
a village, created "Y1lanların Öcü" [Revenge of Snakes] again in a village, and moved to a village to create "Susuz Yaz" when he got the chance to shoot his first film on his account. As a result, the film is a masterpiece of passion.

Metin Erksan is a passionate person. His passion of knowing the hometown, narrating the people, making good films, being a respectful and important person, being regarded as powerful are heavily felt in Erksan's life and all his works. These passions makes his films have a unique wild world integrating the passions of the characters in his works. Erksan achieved the first goal necessary for creating a great piece of art and found his own world. It is very important to focus on the behavioral relations between Erksan who has a wild community and has a constant conflict with himself, who constantly fights with himself, who tries every way to reach the goal, and the Çakıcı Mehmet Efe who rebels against government authority for revenge in "Dokuz Dağın Efesi" [Bandit of Nine Mountains], the youngsters who illegally come together even though they have different aims in "Gecelerin Ötesi" [Beyond the Nights], villagers which make the conflicts that does not go beyond the borders of the village unbearable in "Y1lanların Öcü", docker who tries to change class to revenge for his pain in "Ac1 Hayat", the rich boy who totally goes crazy before each blockage because he is agonized by financial and sexual power in "Suçlular Aramızda" [Criminals Among Us]. "Susuz Yaz" is one of the highest hills of this world of passions.

What makes "Susuz Yaz" a great work of art is that it achieves to approach to land and water property in the story, sexual behaviors of Turkish villagers in a correct way from Erksan's perspective. The fact that a self-trained farmer's passion of possessing the water extracted from the land and his brother's wife is depicted as a one-dimensional presentation of violence by some Western humanist filmmakers or writers stems from their lack of knowledge about the grotesque 
characteristics of Eastern arts. "Susuz Yaz" can fuse the tragic and comic narrative, which is a feature of Eastern arts, very successfully. An extremely moving camera, unusual and surprising camera angles, exaggerated plays help Erksan found his grotesque world appropriately.

If "Susuz Yaz" is a lawless volcanic piece of a passionate filmmaker who wants to prove his power, "Sevmek Zamanı", which was made after he was awarded "Golden Bear" is the segregation of the artist who reached his goal after the storm and his contemplation.

In his essay titled "Sevmek Zamanı Neyi Anlatır veya Sinema Üzerine Düşünme” [What Time to Love narrates or Thoughts on Cinema] which he wrote in Görüntü magazine he says that this film narrates human. If Erksan incriminates his beloved film for the individualism and humanism of the West with these words, "Sevmek Zamanı" is a film which have the greatness and power to stand against all kinds of accusation, even those who come from its creator.

The story of "Sevmek Zamanı", narrating a boy who falls in love with the picture of a girl before herself is very similar to classical folk stories like "Güllühan and Melikşah" and "Elif and Mahmut". The story of "blind love" narrated in the film happens between three or four people, but luckily Erksan does not attempt to investigate and represent such useless things as the psychological depths and personal qualities of these people. Instead, he puts forward a certain sound which comes out of his and our society's collective conscience. The sound of "blind love" is provided not with the inappropriate actions of characters which only are their business, but the elements which can be perceived by those who share the same emotions caused by their inner world. Therefore, he puts forward this humane sound of empty rainy streets, wavy isolated beaches, leafless tress of which reflections are on the lake, dreams of misty city reflecting from wet windows, the big picture of the girl, mannequin of bridal gown in a form which is purified 
from human behaviors but in a more effective way. And this is an abstraction unique to Eastern arts which is the result of collective conscience, not an individual and morbid one of the West.

"Sevmek Zamanı" might be hard for those who do not like Ottoman arts, classical music of the royal Ottomans and Divan poetry. When I was watching the films, these lines from Fuzuli's "Leyla and Mecnun" constantly popped into my mind:

Yâ Rab bela-yı aşk ile kı1 âşîna beni

Bir dem bela-yı aşktan etme cüdâ beni

Az eyleme inayetini ehl-i dertten

Yani ki çoh belâlara k1l müptelâ beni

(for translation: Nizami and Colin Turner, Layla and Majnun)

These words are not only the traditional expression of boy's passion for the girl in "Sevmek Zamanı”. It is the key for Eastern asceticism and Erksan's resources of which faith roots exists in "tasavvuf" and the level of his loyalty to his work.

"Sevmek Zamanı" is one of the best examples of traditional Turkish art with its characters depicted as two-dimensional as purified from unnecessary third dimension, unchanging face expressions of the actors just like in miniatures besides their pictures appropriate for a certain sound. It is a shaming response to those who talks ridiculously as such "it is a babbling instead of an image language".

Isn’t “Sevmek Zamanı” an example of folk cinema? Undoubtedly, no. This film made with Erksan's own money was not considered important by anyone other than himself and his acquaintances. Yet the fact that it is not an example of folk art does not devaluate it. Divan poetry, 
classical music of Ottoman royalty and miniatures are not folk arts either, yet they are important basics of our national culture.

Anyway, the difference between folk arts and high class arts of Ottoman society, which does not any classes, does not lie behind the worldview but the sound and speech. "Sevmek Zamanı" where Erksan pushed his limits of knowledge, talent and opportunities and which reflects the depth and elaborateness of Turkish people with its sound, engravings and the world it provides is not only the summit of Turkish cinema, but also world cinema.

Moreover, "Sevmek Zamanı" could not find the interest it deserved in its own land. “Ölmeyen Aşk” which Erksan made later was heavily criticized, even though it was not one of his best films, but again it is one of the most typical examples of his unique and powerful personality. This film adapted by Emily Bronte's Wood on a Windy Day is no longer related to the novel or William Wyler's or Luis Bunuel's films related to the same topic. "Ölmeyen Aşk" is another window which opens to Erksan's world of stormy passions and outstanding images which is full of ambitious, angry, stoic people. That he headed away from a foreign resource and he could not go beyond the borders of it, despite the perfectness of Erksan's unique sound and speech, does not prevent a great piece of art from emerging. Even though "Ölmeyen Aşk” is based on an English novel, it is not an effort for westernism as it is accused, it does not give place to approaching people from the perspective of Western humanism, idolizing the individual and such elements as bourgeois rationalism. Despite all, Erksan could not build a bridge with the collective conscience of Turkish society due to the restrictions caused by the story of the film. As a result, the film cannot reach out of the borders of being personal- but not individualist.

Erksan also made films which includes western influences. In his works of "Gecelerin Ötesi", "Ac1 Hayat", "Suçlular Aramızda" the traces of Western ideology and arts are deeply 
found. Despite this, when the lonely, rebellious and stoic people in his world is investigated, we can find Shiite-Esoteric characteristics instead of Western individualism. It is not a coincidence that Erksan started to direct films adapting the life of an Alevi folk poet. The cinema thinkers and writers, instead of wasting time with the personality of Bergman who investigates where he finds and loses God or of Fellini who tries to establish a balance between Catholic faith and materialistic though, should be deeply interested in Erksan's passionate world, unique cinema personality and art of which roots are based on sources of Turkish ideology.

We do not have to learn and take everything from the West. As Nazım Paşa said on the first page of Devlet Ana, "We are the Ottomans, we have lots of people." 


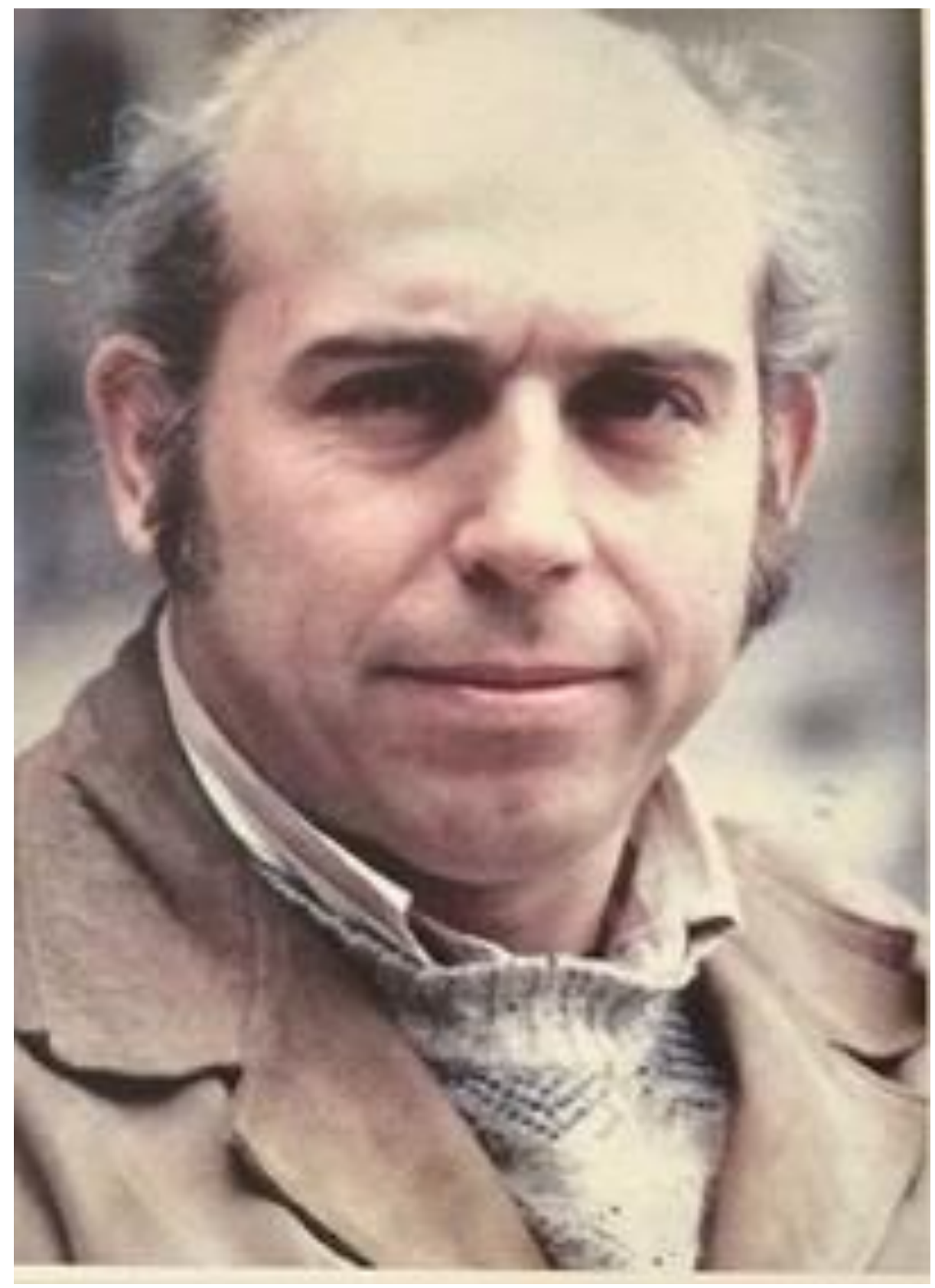

Halit Refiğg (1934-2009) 


\section{BIBLIOGRAPHY}

Akser, Murat. "Changing LGBT Narratives in Turkish Cinema". Reconstruction 16.2 (2016)

Akser, Murat. "Turkish Independent Cinema: Between Bourgeois Auteurism and Political

Radicalism" In Independent Filmmaking Around The Globe, edited by Doris Baltruschat and Mary P. Erickson. Toronto: University of Toronto Press, 2015.

Akser, Murat. Green Pine Resurrected: Film Genre, Parody and Intertextuality in Turkish Cinema. Saarbrücken, Germany: Lambert Academic Publishing, 2010.

Akser, Murat. "The Return of the Repressed: Critique of Turkish Modernity in Halit Refiğ's Films. Unpublished MA Thesis, York University, 2001.

Akser, Murat, and Deniz Bayrakdar, eds. New Cinema, New Media: Reinventing Turkish Cinema. Newcastle-upon-Tyne: Cambridge Scholars Publishing, 2014.

Akser, M., \& Durak-Akser, D. (2017). Fight for a National Cinema: An Introductory Text and Translation (Halit Refĭg, 1971). Film Studies, 16(1), 56-77.

Atakav, Eylem. Directory of World Cinema: Turkey. Bristol: Intellect Ltd, 2013.

Başgüney, Hakkı and Özge Özdüzen eds. The City in Turkish Cinema. Istanbul: Libra, 2014.

Bayrakdar, Deniz ed. Cinema and Politics: Turkish Cinema and the New Europe. Newcastle-uponTyne: Cambridge Scholars Publishing, 2009.

Daldal, Asli. Art, Politics and Society: Social Realism in Italian and Turkish Cinemas. Istanbul: ISIS, 2003.

Derman, Deniz. "Mother-Daughter Relationship in the Family Melodrama: Teyzem." In Gender and Media. Edited By. Nevena Daković, Deniz Derman, and Karen Ross. 100-115. Ankara: MedCampus Publications, 1996.

Karadoğan, Ali. Halit Refiğ: Bir Sinema'nın ve Sinemacı'nın Serüveni. Ankara: DKIV Yayınları, 2003. 
Kayal1, Kurtuluş. Yönetmenler çerçevesinde Türk Sineması üzerine Bir Yorum Denemesi. Ankara: Deniz Kitabevi, 2006.

Kılıç Hristidis, Şengün (der.). Sinemada Ulusal Tavır: 'Halit Refiğ Kitabı'. İstanbul: Türkiye İş Bankası Kültür Yayınları, 2007.

Koksal, Ozlem. World Film Locations: Istanbul. Bristol: Intellect Books, 2012.

Maraşlı, Gülşah Nezaket. Bir Halit Refiğ Filmi. Ankara: Elips Kitap, 2007.

Özdemir, İlker. "Ulusal Sinema Düşüncesinin Politik Toplumsal, Bilimsel, Edebi Yönleri ve Bu Düşüncenin Türk Sinemasına Etkileri’, Ph.D.Diss., Mimar Sinan Güzel Sanatlar Üniversitesi, 1999.

Refiğ, Halit. “Ustalik ve Kisilik Arayanlara” Ulusal Sinema. No.2, 1968.

Refĭğ, Halit. Doğruyu Aradım Güzeli Sevdim. İstanbul: Bizim Kitaplar, 2009.

Sekmeç. Ali Can. Türk Sinemasının "Yorgun Savaşçı"sı Halit Refiğ. İstanbul: İstanbul Büyükşehir Belediyesi Kültür Daire Başkanlığı Yayınları, 2015.

Toklu, Ahmet. Bir Yorgun Savaşçı Halit Refiğ. İstanbul: Sepya Yayıncılık, 2012.

Türeli, Ipek. "Istanbul Through Migrants' Eyes" In Orienting Istanbul: Cultural Capital of Europe. Edited By Deniz Göktürk, Levent Soysal and Ipek Tureli, 144-164.New York: Routledge, 2010.

Türk, İbrahim. Düşlerden Düşüncelere: Halit Refiğ. İstanbul: Kabalcı Yayınevi, 2001. 